Research Article/Araştırma Makalesi

\title{
Teacher Candidates' Viewpoints Regarding General Competencies for Teaching Profession and the Necessity Level of Teaching Profession Courses
}

\author{
Mustafa Öztürk AKCAOĞLU * 1 (D) Erkan KÜLEKÇİ 2 (D) Ezgi MOR-DİRLİK 3 (D) \\ ${ }^{1}$ Kastamonu University, Faculty of Education, Kastamonu, Turkey, ozturk@kastamonu.edu.tr \\ ${ }^{2}$ Kastamonu University, Faculty of Education, Kastamonu, Turkey, ekulekci@kastamonu.edu.tr \\ ${ }^{3}$ Kastamonu University, Faculty of Education, Kastamonu, Turkey, emor@kastamonu.edu.tr \\ * Corresponding Author: ozturk@kastamonu.edu.tr
}

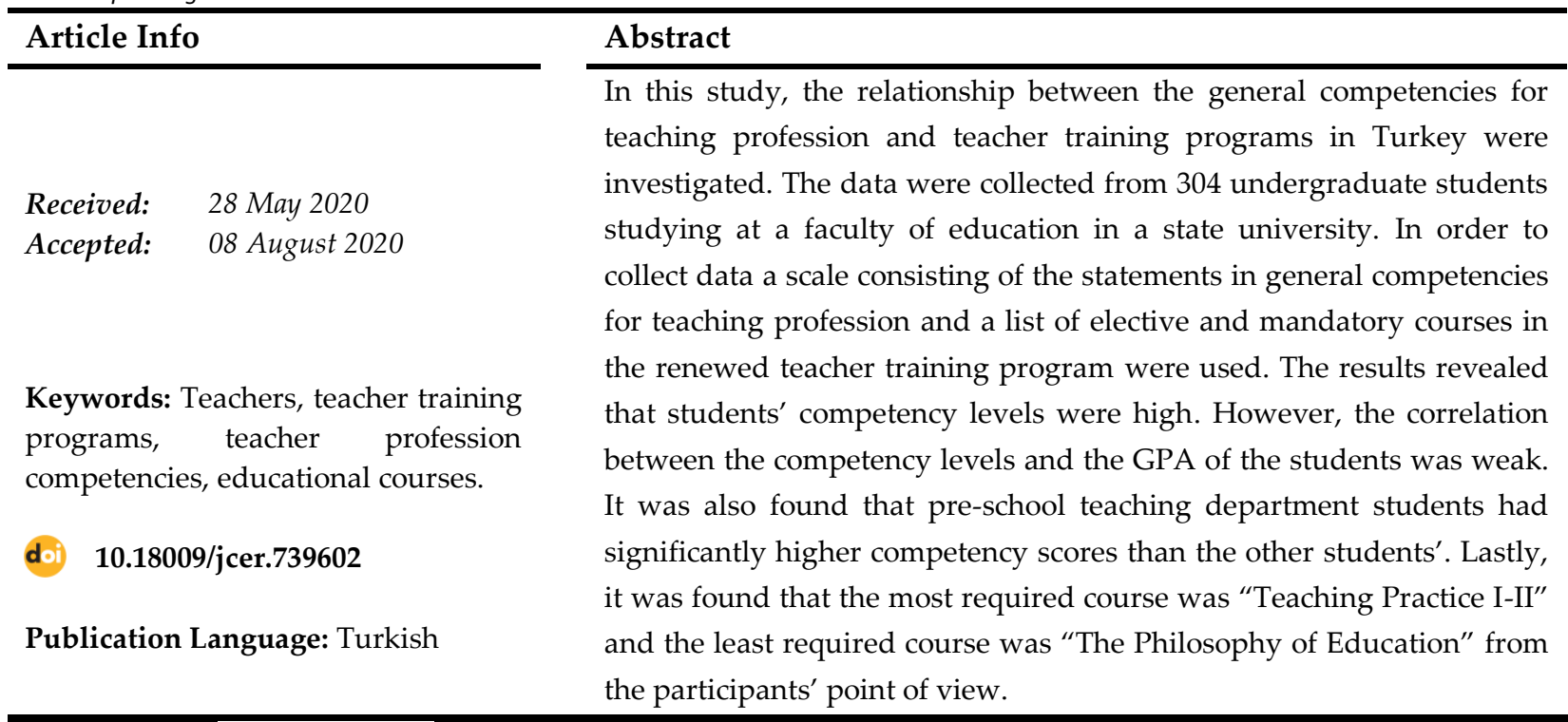

open $\bigcirc$ access $\square$ CrossMark (c)

To cite this article: Akcaoğlu, M. Ö., Külekçi, E. \& Mor-Dirlik, E. (2020). Öğretmen adaylarının bakış açısından meslek bilgisi derslerinin gereklilik düzeyi ve öğretmenlik mesleği yeterlikleri Journal of Computer and Education Research, 8 (16), 545-566. DOI: $10.18009 /$ jcer.739602

\section{Öğretmen Adaylarının Bakış Açısından Meslek Bilgisi Derslerinin Gereklilik Düzeyi ve Öğretmenlik Mesleği Yeterlikleri \\ Makale Bilgisi \\ Öz}

Geliş: $\quad 28$ Mayıs 2020

Kabul: $\quad 08$ Ağustos 2020

Anahtar kelimeler: Öğretmen yetiştirme programı, öğretmenlik mesleği genel yeterlikleri, meslek bilgisi dersleri

10.18009/jcer.739602

Yayım Dili: Türkçe
Bu çalışmada, öğretmenlik mesleği genel yeterlikleri ile öğretmen yetiştirme programları arasındaki ilişki araştırılmıştır. Araştırmanın verileri bir devlet üniversitesinin eğitim fakültesinde öğrenim görmekte olan 304 lisans öğrencisinden toplanmıştır. Veri toplama aracı olarak öğretmen mesleki yeterliklerinden oluşan bir ölçek ve yenilenen öğretmen eğitim programındaki seçmeli ve zorunlu derslerin listesi kullanılmıştır. Araştırma sonuçları öğrencilerin yeterlik düzeylerinin yüksek olduğunu göstermiştir. Ancak, öğrencilerin yeterlik düzeyleri ile genel not ortalamaları arasındaki korelasyonun düşük olduğu belirlenmiştir. Ayrıca, okul öncesi öğretmenliği bölümü öğrencilerinin yeterlik puanlarının diğer öğrencilere göre anlamlı derecede yüksek olduğu bulunmuştur. Son olarak, en gerekli meslek bilgisi dersinin "Öğretmenlik Uygulaması I-II", en az gerekli görülen meslek bilgisi dersinin ise "Eğitim Felsefesi" olduğu belirtilmiştir. 


\section{Summary}

\section{Teacher Candidates' Viewpoints Regarding General Competencies for Teaching Profession and the Necessity Level of Teaching Profession Courses}

\section{Introduction}

In line with the rapid developments in technology and science, nearly all systems have gone through the radical changes. Education systems are one of these systems and since the last decades of the $20^{\text {th }}$ century, new approaches and techniques have been proposed and both students' and teachers' roles have changed. The expected qualities and abilities of students have been diversified and learning by practicing rather than rote learning has become more essential. Hence, the main role of the teachers has been considered as a guide for students' learning process. Due to such changes, teacher training programs have undergone many changes for the last 20 years both in the world and Turkey. One of these changes was to set professional teaching standards, which was firstly published in the USA in 1987 to train highly qualified teachers. In Turkey, the first studies on the teacher professional competencies were started in 1999. Moreover, teacher professional standards were developed and published in 2006 and then the standards were updated in 2017. The competencies in 2017 professional teaching standards include 11 competency domains and 65 indicators. These are the competencies that teachers graduated from faculties of education in Turkey are expected to acquire. The teacher training programs are also expected to cover these competencies in order to meet the goal of raise the quality of education systems. The teacher training programs were updated in 2018 in parallel with the professional competencies and developments in education. Both teacher training programs and the list of competencies have been introduced to the literature relatively new; therefore, there are few studies investigating the relationship between the competencies and the programs. The studies on competencies were about the previous versions and no study has been found examining the newly developed version in a holistic manner. Due to the currency of both issues, in this study, it was aimed to discover the inclusion of the newly developed teacher training programs to the teacher profession competencies based on students' perspectives. 


\section{Method}

This study was carried out in the descriptive model within quantitative research approach. Descriptive research examines the current issues as it is and there is not any intervention. Since the main purpose of this study was to determine the opinions of prospective teachers according to the updated teacher training programs and to determine their professional competencies levels, it was found appropriate to conduct the study in a descriptive model. Data of the study was gathered from 304 senior and third-grade students studying at education faculty of a public university in 2018-2019 academic year. The $66 \%$ of the participants were women $(\mathrm{n}=202)$ and the $34 \%$ of them were men $(\mathrm{n}=102)$ and the ages of the participants ranged between 19 to 23 . Two different data collection tools were utilized and the first one was a self-report scale consisted of 23 indicators of teacher competencies. The participants were asked to state the self-evaluation level of the competencies in fivepoint Likert scale. The scale was developed by the researchers and the factorial structure of it had been analyzed before the real application. The second data gathering tool was the list of educational sciences courses provided as electives and mandatory in the updated teacher training programs. The students were asked to indicate the necessity level of these courses for the teacher profession. Lastly, several sociodemographic information of the participants was included into the study in order to analyze the relationships between the variables and scale scores. For data analyses, descriptive statistics, correlation analyses and ANOVA were performed based on the research questions and all of the estimations were done through the SPSS 22.0 program.

\section{Results}

In line with the research questions, the findings showed that the all participants stated that their competency levels were high and the scale scores of the women were found significantly higher than the men. The competency scores were differed in according to the students' departments and the highest scores were achieved from preschool teaching students and the scores of this group were found significantly higher than all of the other groups. The other finding of the study was that the correlation between the GPA and the competency scale scores was low $(r=, 270)$ but significant. The other findings of the study were related with the necessity levels of educational sciences courses. All of the participants stated that Teaching Practice courses were the most essential and Philosophy of Education 
was the least essential course among the mandatory courses. For the elective ones, while Children Psychology was found the most essential, Anthropology of Education was found as the least essential one. When the preferences of the participants were analyzed based on their competency levels, the students with a higher competency stated that the most essential course among the mandatory ones was Educational Ethic and the least essential one was Sociology of Education. For the elective courses, the preferences of the participants in general and the participants with lower levels of competencies were found the same for the whole group.

\section{Discussion and Conclusion}

Based on the results, all the students stated that their teaching professional competencies were high, and this finding was similar with several related studies' results (Kahyaoğlu and Yangın, 2007; Yenen and Kılıç, 2018). However, departments with the highest competency levels seemed to vary in the literature. Also the low but significant correlation between the students' perceived competency levels and GPA corresponded to several studies. Lastly, the students' preferences about the necessity of the educational sciences courses were analyzed and in different studies, Teaching Practice courses were defined as the most essential by the students as well.

In future studies, some qualitative data along with quantitative data may be collected in order to deepen our understanding on the students' perceptions and opinions about the revised teacher training programs and teacher profession competencies. Also this study has showed that students' preferences should be taken into account especially the process of the determination of the courses. If they have a chance to attend to the courses based on their interests and abilities, they will benefit from the courses more. Moreover, the course selection behaviors of the students might be examined in accordance with the competencies, and the opinions and suggestions of other shareholders can be investigated in order to gather more detailed information. 


\section{Giriş}

Dünyada yaşanan ekonomik ve teknolojik gelişmeler doğrultusunda, toplumsal sistemlerde gerekli görülen değişim, gelişim ve yenilenmeyi gerçekleştirecek nitelikli insan gücünün yetiştirilmesi, eğitim sisteminin asli görevi olarak kabul edilmeye başlanmıştır. Adem (1995, s. 8) tarafından "bireyin yaşam düzeyini yükseltmeye yönelik toplumun yapısını değiştirme" olarak ifade edilen toplumsal gelişmenin sağlanabilmesi için en önemli unsur eğitim sisteminin tüm boyutlarında kalite ve verimliliğin artırılmasıdır. Bu kapsamda, hem bireylere kazandırılması beklenen hem de öğretmenlerin sahip olması gereken yeterlikler günün koşulları ve ihtiyaçları ışığında düzenli olarak güncellenmektedir. Ayrıca, öğrencilerin yeni iletişim teknolojilerini kullanarak bilgiye hızla erişebilmesi, okulun ve öğretmenin geleneksel işlevlerinin yeniden değerlendirilmesini bir zorunluluk haline getirmektedir (World Bank, 2005). Bu doğrultuda eğitimin temel amacı beceri ve bilgilerin kazandırılmasından çok, üst düzey düşünme ve problem çözme becerilerinin geliştirilmesine doğru bir değişim göstermekte; öğretmenin rolü ise öğrenmeyi öğreten, süreçte öğrenciye rehberlik eden ve rol-model olan bir bireye dönüşmektedir. Öğretmenlere yönelik beklentilerin değişmesi, öğretmen yeterliklerinin de değişmesi anlamına gelmektedir. Çünkü eğitimde kalite ve niteliğin temel belirleyicilerinden biri de eğitim sürecini yürüten öğretmenlerdir ve öğretmen yetiştirme sürecinde niteliğin öne çıkarılması eğitim sisteminin işlerliği için önemlidir. Çalışmalarda elde edilen bulgular da öğretmenlerin niteliğinin ve yeterliklerinin öğrencilerin eğitimindeki önemini desteklemektedir. Örneğin, Leigh ve Mead (2005) öğretmen kalitesinin oldukça önemli olduğunu ve öğretmenlerin bilgi ve becerilerinin, öğrencilerin öğrenmesini etkileyen en hayati okul içi faktörlerden olduğunu vurgulamışlardır. Bu amaçla, ilk olarak Amerika Birleşik Devletlerinde 1987'de başarılı öğretmenlerin yetiştirilebilmesi için yüksek standartları koruyarak öğretme ve öğrenme kalitesini artırmak amacıyla Mesleki Öğretim Standartları Ulusal Kurulu (National Board for Professional Teaching Standards) kurulmuştur (Shulman, 2016).

Öğretmen eğitiminde kalite standartlarının belirlenmesi ve izlenmesi, öğretmen niteliğini artırmanın temel yollarından birisidir. Öğretmen yetiştirme sürecinde kalite kavramı "amaca uygunluk derecesi" veya "standartlara uygunluk" olarak belirtilmektedir (Yıldırım, 2002, s. 192). Öğretmen eğitiminde standartlar, öğretmen yetiştirme kurumlarının sunduğu hizmetin niteliğini doğrudan etkileyen ve eğitim hizmetinden yararlanan öğrencilerin sahip olması gereken yeterlik düzeylerini ve bu yeterliklerin öğrencilere 
kazandırılmasında yararlanılan bilgilerin niteliğini kapsamaktadır (Cornell, 1989). Öğretmen Yetiştirme ve Geliştirme Genel Müdürlüğü, öğretmen yeterlikleri kavramını, “öğretmenlik mesleğini etkili ve verimli biçimde yerine getirebilmek için sahip olunması gereken bilgi, beceri ve tutumlar" olarak tanımlamıştır (2017, s. 4). Farklı kaynaklarda yeterlik ya da standartlar olarak çeşitli başlıklarla ifade edilse de bu tanımların hepsinin öğretmenlerin mesleki bilgi, beceri, tutum ve anlayışlarını kapsadığı görülmektedir (Dellinger, Bobbett, Olivier, \& Ellett, 2008). Öğretmenlik yeterliklerinin tanımlanması, sınırlarının çizilmesi mesleğin doğası gereği karmaşık bir nitelik taşımaktadır, çünkü öğretmenlik mesleği ile öğretmenlerin bilgi donanımları ve neler gerçekleştirebilecekleri konusundaki beklentiler dinamik bir yapıya sahiptir (Türk Eğitim Derneği, 2009). Dünyada öğretmen yeterlikleri ile ilgili yapılan çalışmalar öğretmenlerin uygulamada ihtiyaç duydukları yeterliklerin geliştirilmesine, öğretmen eğitimcilerinin sahip olması gereken işlev ve görevlerin belirlenmesine, öğretmenlerin sahip olması gereken bilgi ve becerilere (yeterlilikler) vurgu yapmaktadır (Ilanlou \& Zand, 2011; Koster \& Dengerink, 2001; Pantić \& Wubbels, 2010). Bunun nedenlerinden biri, herhangi bir ülkede eğitim sistemi ile ilgili yapılan bütün reformların, bilimsel yeterliliklere ve mesleki becerilere sahip öğretmenlere bağlı olmasıdır.

Türkiye'de de bu alanda çok sayıda çalışma yapılmış, öğretmenlik mesleği genel yeterlikleri (ÖMGY) Milli Eğitim Bakanlığı ile farklı kurumlar tarafından belirlenmeye ve geliştirilmeye çalışılmıştır (Öğretmen Yetiştirme ve Geliştirme Genel Müdürlüğü, 2017; Türk Eğitim Derneği, 2009). İlk kez Milli Eğitim Bakanlığı tarafından 1999 yılında, öğretmenlerin mesleki yeterliklerinin tanımlanmasına yönelik çalışmalar başlatılmış ve eğitme-öğretme yeterlikleri, genel kültür ve becerileri, özel alan bilgi ve becerileri olarak üç temel başlıkta öğretmen yeterlikleri toplanmıştır (Öğretmen Yetiştirme ve Eğitimi Genel Müdürlüğü, 2002). Farklı kurumların bir araya gelerek yaptıkları kapsamlı çalışmalar sonrasında 2006 yılında ÖMGY, 31 alt yeterlik ve 233 performans göstergesinden oluşacak şekilde düzenlenmiş ve yürürlüğe girmiştir. Zaman içinde ulusal ve uluslararası düzeyde meydana gelen değişiklikler, oluşturulan genel yeterliklerin düzenlenmesini ve güncellenmesini gerektirmiş, bu nedenle 2017 yılında birçok kurum ve kuruluşun görüş, fikir ve destekleri alınarak ÖMGY güncellenmiştir. Bütünsel ve tek bir metin halinde yayımlanan yeterlikler, "mesleki bilgi", "mesleki beceri" ve "tutum ve değerler" olmak üzere birbiri ile ilişkili ve tamamlayıcı nitelikteki üç yeterlik alanı, bunların altında yer alan 11 yeterlik ve bu yeterliklere ilişkin 65 göstergeden oluşmaktadır (Öğretmen Yetiştirme ve Geliştirme Genel Müdürlüğü, 2017, s. 8). 
$\mathrm{Bu}$ yeterlik alanlarının ve yeterliklerin farklı amaçlarla kullanılabileceği belirtilmiştir. Örneğin; öğretmenlerin kendi yetkinlik düzeylerini ve geliştirilmesi gereken yönlerini belirlemede, öğretmen adayı yetiştiren yükseköğretim kurumlarının öğretim programlarının düzenlenmesinde (Dellinger vd., 2008), öğretmenlerin mesleğe kabul ve adaylık süreçlerinde, mesleki gelişim ihtiyaçlarının tespit edilmesinde ve bu ihtiyaçları gidermeye yönelik faaliyetlerin planlamasında, öğretmenlerin performanslarının değerlendirilmesinde, kariyer geliştirmelerinde ve öğretmenlik mesleği statüsünün güçlendirilmesi çalışmalarında söz konusu yeterliklerin temel referans metin olarak kullanılabileceği belirtilmektedir (Öğretmen Yetiştirme ve Geliştirme Genel Müdürlüğü, 2017).

Diğer yandan, güncellenen yeterlikler gibi, öğretmen yetiştirme politikalarında ve programlarında köklü değişimlerin yapılmasının gerekliliği de açıktır. Bu değişimlerden biri de Öğretmen Yetiştirme Lisans Programlarında (ÖYLP) 2018 yılında gerçekleştirilen değişikliklerdir. Söz konusu program kapsamında Meslek Bilgisi derslerine ilişkin değişiklikler yapılmış, mevcut derslere yeni seçmeli ve zorunlu dersler eklenmiş ve ders kredilerinde değişiklikler yapılmıştır. Yenilenen program 2018-2019 Eğitim Öğretim yılında lisans eğitimine başlayan eğitim fakültesi öğretmen adaylarıyla uygulanmaya başlanmıştır. Yeni program ile lisans eğitimi alan öğrencilerin 2023 yılında iş hayatına atılmaları, öğretmen olarak eğitim sistemine dâhil olmaları beklenmektedir. Eğitimde 2023 Vizyonu da göz önünde bulundurulduğunda, yenilenen programdan öğretmen yeterliklerine ilişkin beklentilerin büyük olduğu düşünülmektedir (Milli Eğitim Bakanlığı, 2019). Vizyon belgesinde özellikle yeniliklere açık, kendini geliştiren ve yaşam becerileri kazandıran öğretmen vurgusu yapılmış ve öğretmen yetiştirme ile ilgili “iyi yetişmiş öğretmenlerin olduğu bir sistemde 'çerçeve müfredat' yeterlidir." ifadesine yer verilmiştir (Milli Eğitim Bakanlığı, 2019, s. 9). Diğer yandan, eğitim fakültesi lisans programı mezunlarının daha önce belirlenmiş olan ÖMGY'ye de sahip olması beklenmektedir. Dolayısıyla ÖYLP ile ÖMGY'nin ilişkili olduğu düşünülmekte ve programın öğretmen adaylarına bu yeterlik düzeylerini kazandırması beklenmektedir.

\section{Öğretmen Yeterlikleri ve Meslek Bilgisi Dersleri}

Eğitim ve öğretmen yetiştirme konularının önemi göz önüne alındığında, ÖMGY ve ÖYLP üzerine yapılmış birçok çalışma görmek mümkündür. Bazı araştırmalarda öğretmenlerin ve/veya öğretmen adaylarının öğretmenlik mesleği genel yeterliklerine ya da özel alan yeterliklerine ilişkin algıları ile öz yeterlik düzeyleri incelenmiştir (Numanoğlu \& 
Bayır, 2009; Taşgın \& Sönmez, 2013). Öğretmen adaylarının ÖMGY'ye yönelik algılarını inceleyen çalışmalarda benzer sonuçlara ulaşıldığı ve öğretmen adaylarının kendilerini 'yüksek' veya 'orta' derecede değerlendirdikleri görülmektedir (Numanoğlu \& Bayır, 2009; Seferoğlu, 2004; Shanmugam, 2016; Yenen \& Kılınç, 2018). Ayrıca araştırmacılar, genel yeterliklere ilişkin performans göstergelerinin üst düzeyde kazanılması için “öğretmenlik meslek bilgisi derslerini veren öğretim elemanlarının bu doğrultuda gerekli önemleri almaları ve girişimlerde bulunmaları" gerektiğini vurgulamaktadır (Numanoğlu \& Bayır, 2009, s. 211). Diğer yandan, özel alan yeterlikleriyle ilgili olarak, Ateş (2015) gerçekleştirdiği çalışmada içerik analizi kullanarak Türkçe öğretmenliği lisans programında yer alan derslerin içerikleri ile öğretmen yeterlikleri altındaki özel alan yeterliklerini karşılaştırmıştır. Araştırma sonucunda, ders içeriklerinin yeterlik alanlarından bazılarını tamamen ve bazılarını kısmen karşıladı ̆̆ı, bazılarını da karşılamadı ğı ortaya çıkmıştır.

Yeterlikler konusunda hazırlanan en kapsamlı raporlardan biri de Türk Eğitim Derneği (2009) tarafından gerçekleştirilen çalışmadır. Bu çalışmanın temel amacı, hem ulusal hem de uluslararası bağlamda öğretmenlik meslek standartlarını ele alarak detaylı ve veriye dayalı öğretmenlik mesleği yeterliklerinin gelişmesi için öneriler sunmaktır. Rapor, öğretmen yeterlikleri konusunda gözlemlenen sorunları listelemekte ve “öğretmen yetiştirmede eğitim fakültelerinin mevcut altyapı ve öğretim elemanı eksiklerinin giderilmesi ve öğretmen yetiştirmede uygulamaların çağın gereklerine uygun olarak yeniden düzenlemesi" gibi çözüm önerileri sunmaktadır (Türk Eğitim Derneği, 2009, s. xvii).

Yeterlikler konusunda gerçekleştirilen mevcut çalışmalar incelendiğinde daha çok 2006 yılında yayımlanan ÖMGY üzerine oldukları ve yenilenen yeterliklerle ilgili çalışmaların henüz başlangıç düzeyinde olduğu görülmektedir. Bu nedenle bu çalışmanın hem 2017 'de yenilenen ÖMGY ile ilgili hem de 2018 yılından itibaren uygulanmaya başlayan ÖYLP ile ilgili alana güncel bir katkı sağlayacağı düşünülmektedir.

\section{Araştırmanın Amacı}

Bu araştırma, yenilenen ÖYLP ve ÖMGY'yi aynı kapsamda incelemesi bakımından önemlidir. Geçmişte yapılmış olan araştırmalar incelendiğinde mesleki yeterlikler ve öğretmen yetiştirme programlarına ilişkin çalışmalara rastlanmış ancak özellikle yenilenen öğretmen yetiştirme programları ile güncellenen öğretmen mesleği genel yeterlikleri arasındaki ilişkiyi inceleyen bir çalışma belirlenmemiştir. Bu çalışma, bir önceki ÖYLP bağlamında eğitimine devam eden öğretmen adaylarının mesleki yeterliklere sahip olma 
durumlarını da ortaya koymayı amaçlamaktadır. Ayrıca, 2018 öncesi ÖYLP çerçevesinde öğrenim gören öğretmen adaylarından öğrenim gördükleri süre boyunca almış oldukları meslek bilgisi derslerini ve ders içeriklerini gözeterek, yeni ÖYLP'de yer alan zorunlu ve seçmeli meslek bilgisi derslerinin gereklilik düzeyini belirlemeleri istenmiştir. Böylece hem öğretmen adaylarının mevcut standartları ne düzeyde karşılayabildikleri ile ilgili görüşleri belirlenmiş, hem de durumu iyileştirmek adına alınması gereken önlemler saptanmıştır.

Bu doğrultuda, çalışmada aşağıdaki sorulara cevap aranmaktadır:

1. Çalışmaya katılan öğretmen adaylarının Mesleki Beceri Ölçeğinden (MBÖ) aldıkları toplam puanlara göre mesleki beceri düzeyleri nasıldır?

2. MBÖ’den alınan toplam puanlar öğretmen adaylarının cinsiyetlerine ve bölümlerine göre manidar olarak farklılaşmakta mıdır?

3. MBÖ'den alınan toplam puanlar ile öğretmen adaylarının genel not ortalamaları arasında bir ilişki var mıdır?

4. Öğretmen adaylarının görüşlerine göre yenilenen ÖYLP'de yer alan meslek bilgisi derslerinden hangisi/hangileri en gerekli ve en az gereklidir?

5. MBÖ'den yüksek puan alan öğretmen adayları ile düşük puan alan öğretmen adaylarının en çok ve en az gerekli gördükleri dersler farklılık göstermekte midir?

\section{Yöntem}

\section{Araştırmanın Modeli}

$\mathrm{Bu}$ çalışma, nicel araştırma yaklaşımı içinde yer alan betimsel desende yürütülmüştür. Betimsel araştırmalarda mevcut durumlar herhangi bir müdahale yapılmaksızın olduğu gibi incelenir (Fraenkel ve Wallen, 2007). Bu çalışmanın temel amacı da öğretmen adaylarının yenilenen öğretmen yetiştirme lisans programlarına ilişkin görüşlerinin ve mesleki beceri düzey algılarının belirlenmesi olduğu için çalışmanın betimsel modelde yürütülmesi uygun bulunmuştur.

\section{Çalışma Grubu}

Araştırma kapsamında uygun örneklem yöntemi kullanılmış ve veriler çalışma grubundan toplanmıştır. Çalışma grubu, 2018-2019 akademik yılı bahar döneminde bir devlet üniversitesinin eğitim fakültesinde bir önceki öğretmen yetiştirme lisans programına göre öğrenim gören ve programda yer alan meslek bilgisi derslerinin büyük çoğunluğunu almış olan 3. ve 4. sınıf lisans öğrencilerinden oluşturulmuştur. Çalışma grubunun 3. ve 4. 
sınıf öğrencilerinden oluşturulmasının nedeni, yenilenen öğretmen yetiştirme lisans programına göre öğrenim gören öğretmen adaylarının 1. sınıf düzeyinde olmaları ve eski ile yeni programlarda yer alan meslek bilgisi derslerinin benzerlik göstermesidir. Örneğin, eğitime giriş, eğitim psikolojisi, eğitim felsefesi, öğretim ilke ve yöntemleri, öğretim teknolojileri, sınıf yönetimi, Türk eğitim sistemi ve okul yönetimi, eğitimde ölçme ve değerlendirme gibi temel meslek bilgisi dersleri hem eski hem de yeni programda yer almaktadır. Katılımcıların öğrenim gördükleri bölümlere ve cinsiyetlere göre dağılımı Tablo 1 'de verilmektedir.

Tablo 1. Katılımcıların cinsiyet ve bölümlere göre dağılımı

\begin{tabular}{|c|c|c|c|c|c|c|}
\hline & & \multicolumn{4}{|c|}{ Bölüm } & \multirow[b]{2}{*}{ Toplam } \\
\hline & & $\begin{array}{l}\text { Okul Öncesi } \\
\text { Öğretmenliği }\end{array}$ & $\begin{array}{c}\text { Rehberlik ve } \\
\text { Psikolojik } \\
\text { Danışmanlık }\end{array}$ & $\begin{array}{l}\text { Sosyal Bilgiler } \\
\text { Öğretmenliği }\end{array}$ & $\begin{array}{c}\text { Türkçe } \\
\text { Öğretmenliği }\end{array}$ & \\
\hline & & $\mathrm{f}(\%)$ & $\mathrm{f}(\%)$ & $\mathrm{f}(\%)$ & $\mathrm{f}(\%)$ & $\mathrm{f}(\%)$ \\
\hline \multirow{3}{*}{ Cinsiyet } & Kadın & $53(\% 17)$ & $24(\% 7,9)$ & $65(\% 21,4)$ & $60(\% 19,7)$ & $202(\% 66,4)$ \\
\hline & Erkek & $5(\% 1,6)$ & $14(\% 4,6)$ & $50(\% 16,4)$ & $33(\% 10,9)$ & $102(\% 33,6)$ \\
\hline & Toplam & $58(\% 19,1)$ & $38(\% 12,5)$ & $115(\% 37,8)$ & $93(\% 30,6)$ & $304(\% 100)$ \\
\hline
\end{tabular}

Tablo 1'de yer alan bilgiler incelendiğinde, en fazla katılımcının sosyal bilgiler öğretmenliğinden $(\% 37,8)$ olduğu ardından Türkçe öğretmenliği $(\% 30,6)$, okul öncesi öğretmenliği $(\% 19,1)$ ve rehberlik ve psikolojik danışmanlık $(\% 12,5)$ bölümlerinde öğrenim gören öğretmen adaylarının geldiği görülmektedir. Çalışma grubu cinsiyete göre incelendiğinde, kadın katılımcıların erkek katılımcıların iki katı olduğu ve tüm bölümlerde kadınların erkeklerden sayıca daha fazla olduğu görülmektedir. Katılımcıların yaşları ise 19 ile 23 arasında değişmektedir.

\section{Veri Toplama Araçları}

Çalışmanın temel amacı kapsamında, iki farklı veri toplama aracı kullanılarak nicel veriler toplanmıştır. Bunlardan ilki, araştırmacılar tarafından beş kategorili Likert ölçeği şeklinde hazırlanan 23 maddelik Mesleki Beceri Ölçeğidir (MBÖ). Bu ölçek Öğretmenlik Mesleği Genel Yeterlikleri B bölümünde yer alan mesleki beceri göstergelerinin öz yeterlik bildiren ifadelere dönüştürülmesiyle oluşturulmuştur. Ölçekte “Planlarımı alanımın öğretim programına uygun olarak hazırlayabilirim.”, "Öğretim sürecini planlarken milli ve manevi değerleri dikkate alabilirim." gibi maddeler yer almaktadır. Hazırlanan ölçek formunun geçerliği ve boyutluluk incelemesi için hedef gruba benzer 250 kişilik bir gruba ölçek uygulanmış ve Açımlayıcı Faktör Analizi (AFA) yapılmıştır. AFA uygulanmadan önce normallik, kayıp ve uç değerler, doğrulsallık incelemeleri yapılmıştır. Kayıp verilerin belli 
bir örüntüye sahip olmadığ MCAR testi ile belirlenmiş ve \% 5 'ten az olduğu belirlenen bu veriler için ortalama atama tekniği uygulanmıştır. Örneklem büyüklüğünün uygunluğunu belirten KMO değeri 0,85 olarak bulunmuş ve örneklemin yeterli düzeyde olduğu sonucuna ulaşılmıştır. Manidar olduğu belirlenen Bartlett testi ile ölçeğin faktör analizine uygun olduğu sonucuna ulaşılmıştır (Tabachnick \& Fidell, 2006). Temel bileşenler analizi kullanılarak uygulanan AFA sonucunda, tek faktörlü bir yapı gösteren ölçeğin \%56 varyans açıkladığ1 ve madde faktör yüklerinin 0,33 ile 0,54 arasında değiştiği bulunmuştur. Tek boyutlu ölçek için güvenirlik incelemesi Cronbach Alfa katsayısı ile incelenmiştir ve 0,89 olarak hesaplanan bu katsayıdan, ölçeğin iç tutarlılığın yüksek olduğu sonucuna ulaşılmıştır.

MBÖ’ye ek olarak, çalışmanın verilerin toplanmasında kullanılan bir diğer veri toplama aracı ise öğretmenlik meslek bilgisi derslerinin ve gerekliliklerinin sorulduğu bir bilgi formudur. Bu formda yenilenen öğretmenlik lisans programlarında yer alan seçmeli ve zorunlu tüm meslek bilgisi dersleri verilmiş ve öğretmen adaylarından derslerin mesleki becerileri geliştirmek için gereklilik düzeyini 5 kategorili olarak belirtmeleri istenmiştir. Kategoriler 1-çok gereksiz, 2-gereksiz, 3-orta düzeyde gerekli, 4-gerekli ve 5-çok gerekli şeklinde Likert ölçeği formunda oluşturulmuştur.

Son olarak derslere ilişkin oluşturulan bilgi formunun başında, katılımcıların temel bazı değişkenlere ilişkin durumlarını belirlemeyi amaçlayan birkaç soruya yer verilmiştir. Katılımcıların cinsiyetleri, sınıf düzeyleri, bölümleri ve genel akademik not ortalamalarına ilişkin bilgiler istenmiştir. Cinsiyet ve sınıf düzeyi mesleki beceri düzeyi için değişken olarak kabul edildiği için bu formda yer almıştır.

\section{Verilerin Toplanması/İslem}

Verilerin toplanması aşamasına geçilmeden önce, hazırlanan ölçme araçları için gerekli etik kurul izinleri alınmıştır. Veriler, 2018-2019 akademik yılı bahar döneminde ders dışı zamanlarda sınıf ortamında toplanmış ve katılımcıların gönüllügü temel alınmıştır. Sınıf içindeki uygulamalar yaklaşık 10 dakika sürmüştür. Ayrıca çalışmanın temel amacının görüş belirlemek olduğu ve elde edilen sonuçlara ilişkin herhangi bir yaptırımın olmayacağı katılımcılara açıklanmış ve samimi yanıtlar vermeleri konusunda katılımcılar motive edilmiştir. Veri toplama aşaması yaklaşık 3 hafta sürmüş ve veriler araştırmacılar tarafından toplanmıştır. 


\section{Verilerin Analizi}

Belirtilen ölçme araçları kullanılarak toplanan verilerle, çalışmanın araştırma soruları gözetilerek çeşitli istatistiksel analizler yapılmıştır. MBÖ'den elde edilen puanların katılımcıların cinsiyet ve bölümlerine göre dağılımının incelenmesi için betimsel analizler yapılmıştır. Toplanan veriler üzerinde ilk olarak kayıp ve uç değer incelemesi yapılmıştır. Kayıp değerlerin, veri setinin \%5'inden daha az olduğu ve seçkisiz olarak değiştiği belirlenmiş ve kayıp veri içeren 6 kişiye ilişkin yanıt örüntüsü veri seti dışında bırakılmıştır. Uç değerler için Z değerleri ve Mahalanobis katsayıları hesaplanmıştır. Z değerleri için sınır değer 3 olarak kabul edilmiştir (Field, 2009). Yapılan incelemeler sonucunda -3'ün üzerinde Z puanına sahip olan bir katılımcıya ilişkin veriler veri seti dışında tutulmuştur. Mahalanobis uzaklıkları incelendiğinde ise uç değer olmadığı belirlenmiştir.

Veri setinin analize hazır hale getirilmesinin ardından ilk araştırma sorusuna yanıt bulmak için MBÖ toplam puanları üzerinden betimsel analizler yapılmış, merkezi eğilim ölçüleri ve dağılım ölçüleri hesaplanmıştır. MBÖ’den elde edilen puanların cinsiyet ve bölümlere göre farklılaşma durumunu incelemek için iki yönlü varyans analizi (ANOVA) kullanılmıştır. Ancak bu analize geçilmeden önce, söz konusu tekniğin uygulanabilmesi için gerekli olan bir takım varsayımlar test edilmiştir. Bunlar; bağımlı değişkene ilişkin ölçümlerin grupların ait oldukları evrende normal dağılım göstermesi, gözlemlerin eşit varyansa sahip olması, bir diğer ifadeyle varyansların homojenliği ve gözlemlerin birbirinden bağımsız olmasıdır. Normallik varsayımı tek değişkenli olarak çarpıklık, basıklık katsayıları ve histogramlar kullanılarak incelenmiştir (Field, 2009). Çarpıklık ve basıklık katsayılarının hem gruplar düzeyinde hem de grubun tümünde sınır değer olan 1 ve -1 arasında olduğu belirlenmiş, dolayısıyla tek değişkenli normalliğin sağlandığı sonucuna ulaşılmıştır. Çok değişkenli normallik için ise ölçek puanlarına ilişkin dağılma diyagramları (scatter plot) oluşturulmuş ve elips şeklinde dağılımların olduğu görülmüştür. Bu sonuca göre değişkenler için normallik ve doğrusallık varsayımlarının karşılandığı belirlenmiştir.

Çalışma kapsamında yanıt aranan sorulardan bir diğeri olan MBÖ puanları ile genel akademik not ortalamaları arasındaki ilişki, veriler normal dağılıma uygun olduğu için Pearson Momentler Çarpımı korelasyon katsayıları ile incelenmiştir. Son olarak da ders listesi ile toplanan verilere ilişkin derslerin gereklilik durumlarına ilişkin katılımcı görüşleri ortalama değerler ile incelenmiştir. Analizler SPSS 22.0 programı kullanılarak gerçekleştirilmiştir. 


\section{Bulgular}

Elde edilen bulgular, araştırma sorularının sıralaması takip edilerek verilmiştir. Çalışmada yanıt aranan ilk araştırma sorusu çalışmaya katılan öğretmen adaylarının mesleki beceri düzeylerine ilişkin algılarının hangi seviyede olduğudur. Bu araştırma sorusuna yanıt aranırken öğretmen adaylarının cinsiyetleri ve okudukları bölümler de değişken olarak ele alınmış ve mesleki beceri düzeylerinin bölümlere ve cinsiyete göre nasıl değiştiği incelenmiştir. Mesleki beceri puanlarına ilişkin hesaplanan betimsel istatistikler Tablo 2'de sunulmuştur.

Tablo 2. Mesleki beceri ölçeğinden elde edilen puanlara ilişkin betimsel istatistikler

\begin{tabular}{lcccccccccc}
\hline Grup & $\mathrm{n}$ & $\begin{array}{c}\text { Ortala } \\
\text { ma }\end{array}$ & Medyan & Mod & S.Sapma & Çarpıklık & Basıklık & $\begin{array}{c}\text { En } \\
\text { Düşük }\end{array}$ & $\begin{array}{c}\text { Yüksek } \\
\text { Ranj }\end{array}$ \\
\hline Kadın & 202 & 95,81 & 96 & 93,5 & 10,74 &,- 41 &, 25 & 58 & 115 & 57 \\
\hline Erkek & 102 & 90,38 & 90 & 90,2 & 11,40 &, 05 &,-55 & 66 & 112 & 46 \\
\hline $\begin{array}{l}\text { Tüm } \\
\text { Grup }\end{array}$ & 304 & 93,99 & 94 & 91 & 11,24 &,- 27 &,-23 & 58 & 115 & 57 \\
\hline
\end{tabular}

Tablo 2'de katılımcıların MBÖ'den aldıkları puanlara ilişkin betimsel istatistikler verilmektedir. Ortalama değerler incelendiğinde tüm grupta 94, erkeklerde 90, kadınlarda ise 96 olduğu belirlenmiştir. Mod ve medyan değerlerinin de ortalamaya yakın olduğu belirlenmiş, dolayısıyla dağılımların normale yakın olduğu sonucuna ulaşılmıştır. Çarpıklık ve basıklık değerlerinin de 1 ile -1 arasında yer alması normal dağılıma kanıt oluşturmaktadır. En düşük değerin 58, en yüksek değerin de 115 olarak hesaplandığı göz önünde bulundurulduğunda, grubun büyük çoğunluğunun yüksek puanlar aldığı, dolayısıyla mesleki beceriler bakımından kendilerini yeterli gördükleri öne sürülebilir. Bu durum, kadınlarda ve tüm grup düzeyinde negatif çarpıklık değerleri ile doğrulanmaktadır. $\mathrm{Bu}$ değerlere göre, grubun genel ortalamasının yüksek olduğu, kadın katılımcıların erkeklere göre mesleki beceriler konusunda kendilerini daha yeterli gördükleri sonucuna ulaşılmaktadır.

Tablo 3. Mesleki beceri ölçeğinden elde edilen puanlara ilişkin bölümlere göre betimsel istatistikler

\begin{tabular}{lcccccccccc}
\hline \multicolumn{1}{c}{ Bölüm } & $\mathrm{N}$ & $\begin{array}{c}\text { Ortalam } \\
\mathrm{a}\end{array}$ & Medyan & Mod & ss & Çarpıklık & Basıklık & $\begin{array}{c}\text { En } \\
\text { Düşük }\end{array}$ & $\begin{array}{c}\text { En } \\
\text { Yüksek }\end{array}$ & Ranj \\
\hline Okul Öncesi & 58 & 100,24 & 99 & 97 & 10,58 &,- 54 &,- 39 & 72 & 115 & 43 \\
\hline Sosyal Bilgiler & 38 & 91,16 & 91 & 93,5 & 9,76 &,- 13 &,- 15 & 66 & 112 & 57 \\
\hline PDR & 115 & 92,94 & 92 & 90,2 & 10,02 &, 09 &,- 53 & 70 & 111 & 46 \\
\hline Türkçe & 93 & 94,02 & 94 & 91 & 12,39 &,- 53 &, 04 & 58 & 115 & 57 \\
\hline
\end{tabular}


MBÖ'den elde edilen puanların bölümlere göre nasıl değişim gösterdiği, Tablo 3 'te verilen değerlerde görülmektedir. Tablo değerleri incelendiğinde en yüksek ortalama puanın okul öncesi öğretmenliği bölümünde öğrenim gören katılımcılar tarafından alındığı, ikinci olarak Türkçe öğretmenliği bölümü, üçüncü olarak ise rehberlik ve psikolojik danışmanlık (PDR) bölümünde öğrenim gören öğrenciler olduğu görülmektedir. En düşük ortalama puanı alan grubun ise sosyal bilgiler öğretmenliği bölümünde okuyan öğrencilere ait olduğu belirlenmiştir. Çarpıklık ve basıklık değerleri tüm gruplar için normal sınırlar içinde yer almaktadır. Standart sapma değerleri incelendiğinde ise sosyal bilgiler öğretmen adaylarının en homojen, Türkçe öğretmen adaylarının ise en heterojen grup olduğu görülmektedir.

Bir diğer araştırma sorusu Mesleki Beceri Ölçeğinden elde edilen toplam puanların cinsiyete ve bölümlere göre manidar olarak farklılık gösterip göstermediğidir. Bu araştırma sorusu iki yönlü varyans analizi ile incelenmiş ve elde edilen bulgular Tablo 4'te verilmiştir.

Tablo 4. Cinsiyet ve öğrenim görülen bölümlere göre iki yönlü varyans analizi sonuçları

\begin{tabular}{lccccc}
\hline $\begin{array}{l}\text { Varyansın } \\
\text { Kaynağı }\end{array}$ & $\begin{array}{c}\text { Kareler } \\
\text { Toplamı }\end{array}$ & Sd & $\begin{array}{c}\text { Kareler } \\
\text { Ortalamas }\end{array}$ & F & $\mathrm{p}$ \\
\hline Cinsiyet & 657,39 & 1 & 657,33 & 5,71 &, 02 \\
\hline Bölüm & 3231,32 & 3 & 1077,11 & 9,20 &, 00 \\
\hline Cinsiyet * Bölüm & 75,32 & 3 & 25,11 &, 22 &, 88 \\
\hline Hata & 34088,71 & 296 & 115,17 & & \\
\hline Toplam & 38043,07 & 304 & & & \\
\hline
\end{tabular}

Tablo $4^{\prime}$ te cinsiyete ve öğrenim görülen bölümlere göre yapılan iki yönlü varyans analizi sonuçları yer almaktadır. Cinsiyetin, MBÖ'den elde edilen puanlar üzerinde anlamlı bir farka yol açtığı elde edilen bulgular arasındadır. Öğrenim görülen bölüm de ölçekten elde edilen puanları manidar olarak farklılaştırmaktadır. Cinsiyet bölüm ortak etkileşiminin ise manidar bir farka yol açmadığı bulunmuştur. Bölümler arası farklılaşmanın belirlenmesi için ise çoklu karşılaştırma testleri kullanılmıştır. Yapılan çoklu karşılaştırma sonuçları Tablo 5 'te verilmiştir.

Tablo 5. Çoklu karşılaştırmalar

\begin{tabular}{|c|c|c|c|c|c|c|c|}
\hline & \multirow{2}{*}{ (I) Bölüm } & \multirow{2}{*}{ (J) Bölüm } & \multirow{2}{*}{$\begin{array}{c}\text { Ortalamalar } \\
\text { Farkı (I-J) }\end{array}$} & \multirow{2}{*}{$\begin{array}{l}\text { Standart } \\
\text { Hata }\end{array}$} & \multirow[b]{2}{*}{$\mathrm{p}$} & \multicolumn{2}{|c|}{ 95\% Güven Aralığı } \\
\hline & & & & & & Alt sinir & Üst sinır \\
\hline \multirow[t]{10}{*}{ Scheffe } & Okul öncesi & PDR & $7,29401^{*}$ & 2,25778 & ,016 & ,9464 & 13,6416 \\
\hline & & Sosyal Bil. & $9,08486^{*}$ & 1,74226 & ,000 & 4,1866 & 13,9831 \\
\hline & & Türkçe & $6,21987^{*}$ & 1,81003 & ,009 & 1,1311 & 11,3086 \\
\hline & PDR & Okul öncesi & $-7,29401^{*}$ & 2,25778 & 016 & $-13,6416$ &,- 9464 \\
\hline & & Sosyal Bil. & 1,79085 & 2,02422 & ,854 & $-3,9001$ & 7,4818 \\
\hline & & Türkçe & $-1,07414$ & 2,08284 & ,966 & $-6,9299$ & 4,7816 \\
\hline & Sosyal Bil. & Okul öncesi & $-9,08486^{*}$ & 1,74226 & ,000 & $-13,9831$ & $-4,1866$ \\
\hline & & PDR & $-1,79085$ & 2,02422 & ,854 & $-7,4818$ & 3,9001 \\
\hline & & Türkçe & $-2,86498$ & 1,50867 & ,309 & $-7,1065$ & 1,3765 \\
\hline & Türkçe & Okul öncesi & $-6,21987^{*}$ & 1,81003 & ,009 & $-11,3086$ & $-1,1311$ \\
\hline
\end{tabular}


Akcaoglu, Külekçi \& Mor-Dirlik

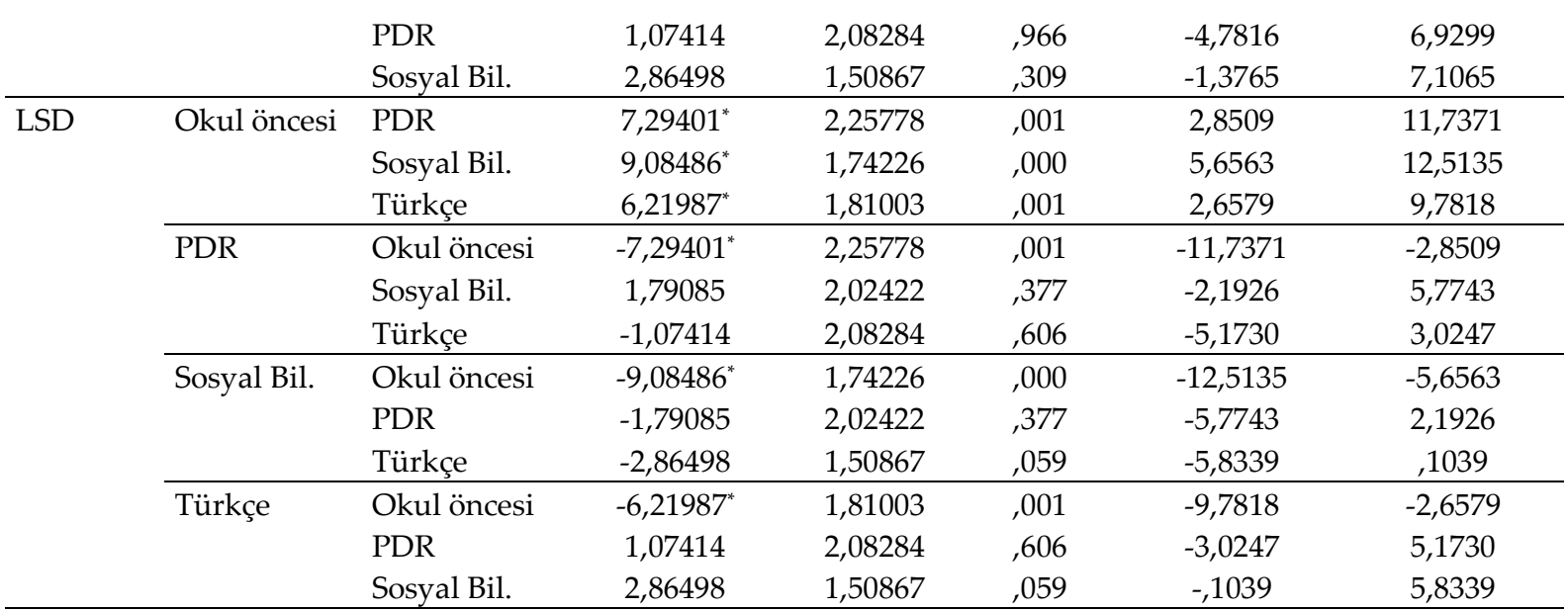

Tablo 5'te bulguları verilen çoklu karşılaştırmalar için Scheffe ve LSD olmak üzere iki ayrı test kullanılmıştır. Her iki testten de elde edilen bulgular benzer niteliktedir. Yalnızca okul öncesi öğretmenliği bölümünde öğrenim gören öğrencilerin MBÖ’den aldıkları puanlar tüm bölümlerden manidar olarak yüksektir. Sosyal bilgiler öğretmenliği, PDR ve Türkçe öğretmenliği bölümlerinde öğrenim gören öğrencilerin aldıkları puanlar arasındaki farklar manidar bulunamamıştır. İki yönlü varyans analizi bulguları genel olarak yorumlandığında, ilgili bölümlerde öğrenim gören kadın öğrencilerin erkek öğrencilere göre mesleki beceriler bakımından kendilerini daha yeterli gördükleri ve incelemeye alınan dört bölümden en yüksek puanı alan okul öncesi öğretmenliği bölümündeki öğrencilerin mesleki beceri puanlarının diğer bölümlerdeki öğrencilerden manidar olarak daha yüksek olduğu bulunmuştur. Öğrenim görülen bölüm ve cinsiyet etkileşiminin ise mesleki beceri puanlarında anlamlı bir farka yol açmadığı belirlenmiştir.

Çalışma kapsamında yanıt aranan bir diğer araştırma sorusu ise, MBÖ'den alınan puanlar ile öğretmen adaylarının genel not ortalamaları (GNO) arasında manidar bir ilişkinin olup olmadığıdır. Bu iki değişken arasındaki korelasyon, Pearson Momentler Çarpımı Korelasyon Katsayısı kullanılarak incelenmiştir. Elde edilen bulgular Tablo 6'da verilmiştir.

Tablo 6. MBÖ ile genel not ortalaması arasındaki ilişki

\begin{tabular}{|c|c|c|c|}
\hline \multicolumn{2}{|c|}{ Pearson KK } & GNO & MBÖ \\
\hline \multirow{2}{*}{ GNO } & Pearson KK & &, $27^{* *}$ \\
\hline & $\mathrm{P}$ & & ,00 \\
\hline
\end{tabular}

**. 0.01 düzeyinde manidar korelasyonu göstermektedir.

Tablo 6'da öğretmen adaylarının genel not ortalaması ile MBÖ'den aldıkları puanlar arasındaki korelasyon katsayısı verilmektedir. Elde edilen değerler incelendiğinde iki puan seti arasında 0,01 düzeyinde manidar ancak düşük bir ilişki olduğu görülmektedir. Bu 
bulgular göz önünde bulundurulduğunda, MBÖ’den elde edilen puanlar ile genel akademik not ortalaması arasındaki ilişkinin düşük olduğu sonucuna ulaşılmaktadır.

Çalışma kapsamında yanıt aranan son soru ise öğretmen adaylarının yeni öğretmen yetiştirme lisans programında yer alan derslerden hangi/hangilerini en çok gerekli ve en az gerekli olarak gördüklerinin belirlenmesidir. 15'i zorunlu ve 22'si seçmeli olmak üzere toplam 37 meslek bilgisi dersinden, öğretmen adaylarının en çok gerekli gördüğü zorunlu meslek bilgisi dersinin Öğretmenlik Uygulaması I ve II $(f=4,66)$, en az gerekli gördükleri zorunlu meslek bilgisi dersinin ise Eğitim Felsefesi $(f=3,46)$ olduğu belirlenmiştir. Seçmeli dersler için yapılan incelemelerde ise öğretmen adayları tarafından en çok gerekli olduğu düşünülen dersin Çocuk Psikolojisi $(\mathfrak{f}=4,48)$, en az gerekli olduğu düşülen dersin ise Eğitim Antropolojisi $(\mathrm{f}=2,80)$ olduğu belirlenmiştir. Zorunlu ve seçmeli derslerin ortalamaları incelendiğinde, zorunlu derslerin ortalamalarının seçmelilere göre genel olarak daha yüksek olduğu belirlenmiştir.

Yeni ÖYLP'de yer alan dersler ile ilgili yanıt aranan bir diğer araştırma sorusu ise MBÖ'den yüksek puan alanlar ile düşük puan alan öğretmen adaylarının en çok ve en az gerekli gördükleri derslerin nasıl değiştiğidir. Bu amaçla 304 kişiden oluşan veri seti MBÖ'den elde edilen toplam puanlara göre sıralanmış, ilk 100'de yer alan bireyler yüksek puan alanlar olarak gruplandırılmış, son 100'de yer alan katılımcılar ise düşük puan alan grup olarak tanımlanmıştır. MBÖ’ye göre alt grupta yer alan öğretmen adaylarının en gerekli ve en az gerekli olarak nitelendirdikleri seçmeli ve zorunlu derslerin tüm gruptan elde edilen dersler ile aynı olduğu belirlenmiştir. En gerekli dersler, zorunlu derslerden Öğretmenlik Uygulaması I-II ( $f=4,67)$, seçmeli derslerden ise Çocuk Psikolojisi $(f=4,31)$ olarak belirlenmiştir. En az gerekli görülen derslerden de Eğitim Felsefesi $(\mathfrak{f}=2,61)$ zorunlu dersler kategorisinde, Eğitim Antropolojisi $(\mathrm{f}=2,62)$ ise seçmeli dersler kategorisinde yer almaktadır.

MBÖ'den aldıkları puanlara göre üst grupta yer alan katılımcılardan elde edilen bulgular incelendiğinde ise, zorunlu dersler içinde en gerekli dersin Eğitimde Ahlak ve Etik ( $f=4,96)$ olduğu, en az gerekli görülen dersin ise Eğitim Sosyolojisi $(f=4,10)$ olduğu belirlenmiştir. MBÖ'den yüksek puan alan öğretmen adaylarının seçmeli meslek bilgisi derslerinden en gerekli gördükleri dersin tüm katılımcılarda olduğu gibi Çocuk Psikolojisi $(\mathrm{f}=4,74)$, en az gerekli gördükleri dersin ise yine tüm grupta olduğu gibi Eğitim Antropolojisi $(\mathrm{f}=3)$ olduğu belirlenmiştir. Elde edilen bu bulgulara göre MBÖ'den elde edilen puanlara göre oluşturulan alt grubun derslere ilişkin görüşlerinin tüm katılımcı grubuyla aynı olduğu, 
üst grupta ise zorunlu derslerde diğer katılımcılardan farklı olarak Eğitimde Ahlak ve Etik dersinin olduğu belirlenmiştir. Bu bulgular göz önünde bulundurulduğunda, mesleki bilgi düzeyi üst düzeyde olan öğretmen adaylarının farklı meslek bilgisi derslerine ihtiyaç duyduğu şeklinde yorumlanabilir.

\section{Tartışma ve Sonuç}

Bu çalışma kapsamında 2018 yılında uygulanmaya başlanan ÖYLP'de yer alan zorunlu ve seçmeli meslek bilgisi derslerinin bir önceki ÖYLP'de bulunan dersleri alan öğretmen adayları tarafından mesleki yeterliklere göre değerlendirilmesi amaçlanmıştır. Ayrıca, çalışma, bir önceki ÖYLP çerçevesinde eğitimine devam eden öğretmen adaylarının yenilenen ÖMGY'de yer alan mesleki yeterliklere sahip olma durumlarını da ortaya koymayı amaçlamaktadır. Böylece hem öğretmen adaylarının mevcut standartları ne düzeyde karşılayabildikleri belirlenmiş, hem de durumu iyileştirmek adına alınması gereken önlemler saptanmaya çalışılmıştır. Bu amaçlar doğrultusunda elde edilen bulgular incelendiğinde aşağıdaki sonuçlara ulaşılmıştır.

Araştırmanın sonuçlarına göre tüm katılımcıların mesleki yeterlik puanlarının yüksek olduğu bulunmuştur. Elde edilen bu bulgu benzer çalışmaların bulgularıyla örtüşmektedir (Dilci \& Yıldız, 2012; Kahyaoğlu \& Yangın, 2007; Yenen \& Kılınç, 2018). Mevcut çalışmaların katılımcıları, öğretmen ya da öğretmen adayı olarak farklılaşsa da sonuçlar birbirine benzer bulunmuştur. Katılımcılar kendilerini mesleki beceri ve yeterlikler anlamında yüksek düzeyde olarak tanımlamışlardır. Özellikle öğretmen adaylarının öğretmenlere göre daha yüksek mesleki yeterliğe sahip olduğunu gösteren bulguların sebepleri öğretmen adaylığı sürecinde gerçek sınıf ortamında daha az yer almaları ve sınıf sorumluluğunu tam olarak almamış olmaları olabilir. Çalışmanın bir diğer bulgusu, mesleki beceri puanlarının kadın katılımcılarda erkeklere göre manidar olarak daha yüksek olduğu göstermiştir. Konu ile ilgili yürütülmüş diğer araştırmalar incelendiğinde, bazı çalışmaların bu araştırma bulgularına benzer şekilde kadınlar lehine anlamlı sonuçlara ulaştığı (Dilci \& Yıldız, 2012), bazılarının ise cinsiyete göre anlamlı bir bulgu tespit edemediği (Kahyaoğlu \& Yangın, 2007) ya da erkek katılımcılar lehine anlamlı bulgulara ulaştığı (Yenen \& Kılınç, 2018) görülmüştür. Buna göre mesleki beceri ve yeterlik düzeylerinin cinsiyete göre genel bir eğilim göstermediği ve katılımcı grubuna göre farklılaştığı söylenebilir. Bu durum mesleki beceri ve yeterlik düzeylerindeki farklılaşmanın cinsiyete ek olarak diğer değişkenlerin de 
(mesleki kıdem, yaş, okul türü, mezun olunan üniversite vb.) etkisine açık olduğu şeklinde yorumlanabilir.

Bölümlere göre yapılan incelemede ise okul öncesi öğretmenliğinde öğrenim gören öğrencilerin en yüksek puana sahip grup olduğu ve bu farkın diğer gruplarla karşılaştırıldığında manidar olduğu belirlenmiştir. Benzer çalışmalar incelendiğinde anlamlı fark belirlenen grupların değişiklik gösterdiği görülmüştür. Örneğin, Dilci ve Yıldız (2012) sınıf öğretmenliği bölümünde okuyan katılımcıların diğer bölümlerdeki katılımcılara göre daha yüksek düzeyde mesleki yeterlik inancına sahip olduğu bulgusuna ulaşmıştır. Diğer bazı araştırmacılar da anlamlı farklılıkların bölümlere göre değiştiği sonucuna ulaşmışlardır (Gürbüztürk \& Şad, 2009). Sonuçların belirli bölüm lehine tutarlılık göstermemesinin nedeni, mesleki beceri ve yeterliği belirleyen çok sayıda değişkenin (ders içerikleri, öğretim elemanları, lisans yerleştirme puanı, kullanılan yöntem ve teknikler vb.) olması olabilir.

Araştırmada elde edilen bir diğer bulgu, MBÖ'den elde edilen puanlarla katılımcıların genel not ortalamaları arasındaki ilişkinin düşük fakat manidar yönde olduğudur. Bu bakımdan, araştırmanın sonuçları, Ülper ve Bağcı'nın (2012) Türkçe öğretmen adaylarının öz yeterlik algılarını inceledikleri çalışmada, öğretmen adaylarının öz yeterlik algıları ve akademik başarıları arasındaki ilişkiye yönelik sonuçlarıyla benzerlik göstermektedir. Ülper ve Bağcı (2012) çalışmalarında, öğretmen adaylarının öz yeterlik algılarının akademik başarı durumlarına göre anlamlı farklılık gösterdiğini, akademik başarı düzeyleri yüksek olan adayların diğer adaylara göre daha yüksek bir öz yeterlik algısına sahip olduğunu belirtmişlerdir. Öte yandan, sosyal bilgiler öğretmen adayları ile yapılan bir diğer çalışmada, öğretmen adaylarının öğretmenlik mesleğine ilişkin öz yeterlik algılarının akademik başarı puanlarına göre anlamlı bir farklılık göstermediği tespit edilmiştir (Ünlü, Kaşkaya \& Kızılkaya, 2017).

Çalışmada ayrıca, öğretmen adaylarının yeni öğretmen yetiştirme lisans programında yer alan derslerden hangi/hangilerini en çok gerekli ve en az gerekli olarak gördükleri incelenmiştir. Bulgular, en çok gerekli görülen zorunlu meslek bilgisi dersinin Öğretmenlik Uygulaması I ve II olduğunu gösterirken, en az gerekli görülen zorunlu dersin ise Eğitim Felsefesi olduğunu ortaya koymuştur. Seçmeli dersler içerisinde ise en fazla Çocuk Psikolojisi, en az ise Eğitim Antropoloji derslerinin gerekli olduğu bulunmuştur. Bu bulgular ile çalışma, önceki çalışmaları destekler niteliktedir. Örneğin, sınıf öğretmenliği ile ilgili yapılan farklı çalışmalarda, öğretmen adaylarının Öğretmenlik Uygulaması I ve II derslerini 
en çok gerekli ve etkili gördükleri dersler olarak niteledikleri (Süral, 2015; Şahin \& Kartal, 2013) ve bölüm mezunlarının da bu dersleri en çok yararlandıkları dersler arasında sıraladıkları (Yavuzer vd., 2006) görülmektedir. Çalışmanın bulgularıyla paralel olarak, Süral (2015) de sınıf öğretmeni adaylarının en az gerekli gördükleri derslerden birinin Eğitim Felsefesi olduğunu belirmiştir.

Son olarak araştırma kapsamında, MBÖ’den aldıkları puanlara göre alt ve üst gruptaki katılımcıların derslere ilişkin görüşleri incelenmiştir. Buna göre alt grupta yer alan öğretmen adaylarının en gerekli ve en az gerekli gördükleri derslerin tüm grupla aynı olduğu belirlenmiş, ancak üst grupta yer alan katılımcıların en gerekli buldukları derslerin Eğitimde Ahlak ve Etik ile Çocuk Psikolojisi olduğu, en az gerekli buldukları derslerin ise Eğitim Sosyolojisi ve Eğitim Antropolojisi olduğu belirlenmiştir. Ancak, bahsedilen dersler daha çok ÖMGY'nin Tutum ve Değerler başlıklı C bölümünde yer alan göstergelere yönelik içeriğe sahip olduğundan bulguların yorumlanabilmesi için ilgili göstergeleri içeren bir ölçeğin kullanılması gerektiği söylenebilir.

\section{Öneriler ve Sınırlılıklar}

$\mathrm{Bu}$ çalışmada sunulan bulguların öğretmenlik mesleğine ilişkin öğrencilerin yeterlik düzeyleri hakkında bilgi verici olması ve yeni öğretmen yetiştirme lisans programında öğretmen adaylarının en çok ve en az gerekli gördükleri meslek bilgisi derslerini belirlemesi açılarından öğretmen eğitimi ile ilgili tüm paydaşlara gerçekleştirecekleri çalışmalarda katkı sağlayacağı düşünülmektedir.

Çalışma kapsamında oluşturulan mesleki beceri ölçeği, öğretmen adaylarının mesleki beceri düzeylerinin belirlenmesine olanak sağlayacaktır. Böylelikle hem Meslek Bilgisi derslerinin daha etkili olarak yürütülmesine ilişkin alınacak önlemler belirlenebilecek, hem de dersler kapsamında verilmeyen yeterlik göstergelerinin farklı dersler kapsamına dâhil edilerek öğretmen adaylarına kazandırılması sağlanacaktır.

Diğer yandan, seçmeli ders havuzun oluşturulmasında öğrenci görüşlerinin alınması; öğrenci beklentilerinin karşılanmasını sağlayabilir ve öğrencilerin ilgi ve ihtiyaçlarına uygun dersleri almalarına olanak tanıyabilir. Ayrıca, öğretmen adayları tarafından gereklilik düzeyi yüksek olarak belirtilen uygulamaya dönük derslerin sayısının artırılması, öğretmen adaylarının sınıf ortamına daha fazla dâhil olmalarını sağlayabilecektir. Bu kapsamda öğretmen adaylarının öğretmenlik uygulaması dersinde yer alan mikro-öğretim süreci ile 
geliştirilmesi gereklidir (Bhargava \& Pathy, 2011). Böylelikle, beceri ve yeterliklerine ilişkin daha gerçekçi değerlendirmeler yapabilmelerine olanak sağlanmış olacaktır.

Bu çalışma, bir devlet üniversitesinin eğitim fakültesinde Türkçe öğretmenliği, okul öncesi öğretmenliği, sosyal bilgiler öğretmenliği ve rehberlik ve psikolojik danışmanlık bölümlerinde öğrenim gören 3. ve 4. sınıf öğrencilerin verdikleri öz-bildirim cevaplar ile sınırlıdır. Ayrıca, çalışma grubunun eski ÖYLP'deki dersleri almış olmaları ve yeni ÖYLP'de yer alan bazı derslerin farklılaşması bulguların yorumlanmasını göreceli olarak sınırlamıştır. Benzer bir çalışma, yeni öğretmenlik lisans programı ile öğrenim gören öğrencilerin programdaki çoğu dersi almış olacağı bir dönemde tekrar yürütülebilir. İleride yürütülecek çalışmalar, genellenebilirliğin artırılması amacıyla farklı eğitim fakültelerinde ve farklı öğretmenlik bölümlerinde okuyan öğrencileri katılımcı olarak kapsayabilir. Son olarak, daha uzun süreli bir çalışmada, nicel verilerin yanı sıra, odak grup veya bireysel görüşmeler ile ders gözlemlerinin raporlanması şeklinde nitel verilerle de detaylandırıp zenginleştirilebilir.

\section{Bilgilendirme}

Bu çalışmanın bir bölümü 09-12 Ekim 2019 tarihinde Ankara'da gerçekleştirilmiş olan VII. Uluslararası Ĕ̆itim Programları ve Öğretim Kongresinde sunulmuştur.

Bu çalışmada kullanılan verilerin 2020 yılı öncesine ait olduğu araştırmacılar tarafından onaylanmıştır.

Yazar Katkı Beyanı

Mustafa Öztürk Akcaoğlu: Kavramsallaştırma, veri toplama ve analizi, ön taslak yazımı ve düzenleme

Erkan Külekçi: Kavramsallaştırma, veri toplama, danışmanlık ve denetim, inceleme-yazma ve düzenleme

Ezgi Mor Dirlik: Kavramsallaştırma, veri toplama ve analizi, metodoloji, inceleme-yazma ve düzenleme

\section{Kaynaklar}

Adem, M. (1995). Demokratik, laik ve çağdaş eğitim politikası. Ankara: Şafak Matbaacılık.

Ateş, M. (2015). Türkçe öğretmenliği lisans programlarının öğretmen yeterlikleri açısından incelenmesi. International Journal of Social Science, (41), 293-301.

Bhargava, A., \& Pathy, M. (2011). Perception of student teachers about teaching competencies. American International Journal of Contemporary Research, 1(1), 77-81. 
Cornell, R. A. (1989). Standards for College and University Learning Resources Programs. Technology in Instruction. Washington, D.C.: Association for Educational Communications and Technology.

Dellinger, A. B., Bobbett, J. J., Olivier, D. F., \& Ellett, C. D. (2008). Measuring teachers' selfefficacy beliefs: Development and use of the TEBS-Self. Teaching and teacher education, 24(3), 751-766.

Dilci, T., \& Yıldız, H. (2012). Öğretmen adaylarının mesleki yeterliklerine ilişkin inançları. Sosyal Bilimler Araştırmaları Dergisi, 7(1), 245-265.

Field, A. (2009). Discovering statistics using IBM SPSS statistics. Third Edition. Sage Publication.

Fraenkel, J. R., \& Wallen, N. E. (2006). How to design and evaluate research in education with PowerWeb (6th ed.). New York, NY: McGraw-Hill.

Gürbüztürk, O., \& Şad, S. N. (2009). Student teachers? Beliefs about teaching and their sense of self efficacy: A descriptive and comparative analysis. Inönü Üniversitesi Ĕ̆itim Fakültesi Dergisi, 10(3), 201-226.

Ilanlou, M., \& Zand, M. (2011). Professional competencies of teachers and the qualitative evaluation. Procedia-Social and Behavioral Sciences, 29, 1143-1150.

Kahyaoğlu, M., \& Yangın, S. (2007). İlköğretim öğretmen adaylarının mesleki özyeterliklerine ilişkin görüşleri. Kastamonu Ĕ̆gitim Dergisi, 15(1), 73-84.

Koster, B., \& Dengerink, J. (2001). Towards a professional standard for Dutch teacher educators. European Journal of Teacher Education, 24(3), 343-354.

Leigh, A., \& Mead, S. (2005). Lifting Teacher Performance. Policy Report. Erişim adresi: https://files.eric.ed.gov/fulltext/ED491196.pdf

Milli Eğitim Bakanlığı. (2019). 2023 eğitim vizyonu. Erişim adresi: http://2023vizyonu.meb.gov.tr/doc/2023_EGITIM_VIZYONU.pdf

Numanoğlu, G., \& Bayır, Ş. (2009). Bilgisayar öğretmen adaylarının öğretmenlik mesleği genel yeterliklerine ilişkin görüşleri. Journal of Kırşehir Education Faculty, 10(1), 197-212.

Öğretmen Yetiştirme ve Eğitimi Genel Müdürlüğü. (2002). Öğretmenlik mesleği genel yeterlikleri. Erişim adresi: https://oygm.meb.gov.tr/meb_iys_dosyalar/2017_12/13161921_YYretmenlik_MesleYi_ Genel_YETERLYKLERi_onaylanan.pdf

Öğretmen Yetiştirme ve Geliştirme Genel Müdürlüğü. (2017). Öğretmenlik mesleği genel yeterlikleri. Erişim adresi: https://oygm.meb.gov.tr/www/ogretmenlik-meslegi-genelyeterlikleri/icerik/39

Pantić, N., \& Wubbels, T. (2010). Teacher competencies as a basis for teacher educationViews of Serbian teachers and teacher educators. Teaching and teacher education, 26(3), 694-703.

Seferoğlu, S. S. (2004). Öğretmen yeterlilikleri ve mesleki gelişim. Bilim ve Aklın Aydınlı̆̆ında Ĕ̈itim, 58, 40-45. 
Shanmugam, P. N. (2016). A study on differential aptitude and teaching competency of student teachers in kancheepuram district. Journal of Education and Practice, 7(13), 8788 .

Shulman, L. S. (2016). What teachers should know and be able to do. Erişim adresi http://accomplishedteacher.org/wp-content/uploads/2016/12/NBPTS-What-TeachersShould-Know-and-Be-Able-to-Do-.pdf

Süral, S. (2015). Sınıf öğretmenliği öğretmen adaylarının öğretmen yetiştirme programındaki derslerin gerekliliği ve işe vurukluk düzeyleri hakkındakı görüşleri. Trakya Üniversitesi Ĕ̆itim Fakültesi Dergisi, 5 (1), 34-43.

Şahin, Ç, \& Kartal, O. (2013). Sınıf öğretmeni adaylarının sınıf öğretmeni yetiştirme programı hakkındaki görüşleri. Uşak Üniversitesi Sosyal Bilimler Dergisi, 6 (1), 164-179.

Taşgın, A., \& Sönmez, S. (2013). Evaluation of general qualifications of teaching profession according to classroom teachers and classroom teacher candidates' opinions. Middle Eastern \& African Journal of Educational Research, 3, 80-90.

Türk Eğitim Derneği (2009). Öğretmen yeterlikleri özet raporu. Erişim adresi: http://portal.ted.org.tr/yayinlar/Ogretmen_Yeterlik_Kitap_Ozet_rapor.pdf

Ülper, H. \& Bağcı, H., (2012). Türkçe öğretmeni adaylarının öğretmenlik mesleğine dönük öz yeterlik alg1ları. Turkish Studies (Elektronik), 7(2), 1115-1131.

Ünlü, İ., Kaşkaya, A. \& Kızılkaya, M. F. (2017). Sosyal bilgiler öğretmen adaylarının özyeterlik inançlarının çeşitli değişkenler açısından incelenmesi. Ahi Evran Üniversitesi Kırşehir Eğitim Fakültesi Dergisi (KEFAD) 18(2), 651-668

World Bank. (2005). Learning to teach in the knowledge society. Erişim adresi http://documents.worldbank.org/curated/en/748131468339060098/Vietnam-Learningto-teach-in-a-knowledge-society

Yavuzer, Y., Dikici, A., Çalışkan, M., \& Aytekin, H., (2006). Sınıf öğretmenliği mezunlarının öğretmen yetiştirme programlarından yararlanma düzeylerine ilişkin görüşleri. Çukurova Üniversitesi Ĕ̆itim Fakültesi Dergisi, 3(32), 35-41

Yenen, E. T., \& Kılınç, H. H. (2018). Öğretmenlerin öğretmenlik mesleği genel yeterliklerine sahip olma düzeylerinin incelenmesi. Uluslararası Türkçe Edebiyat Kültür Eğitim (TEKE) Dergisi, 7(4), 2767-2787.

Yıldırım, H. (2002). Toplam kalite yönetiminin temel kavramları. Öneri Dergisi, 5(17), 191202.

JCER's Publication Ethics and Publication Malpractice Statement are based, in large part, on the guidelines and standards developed by the Committee on Publication Ethics (COPE). This article is available under Creative Commons CC-BY 4.0 license (https://creativecommons.org/licenses/by/4.0/) 